\title{
鋼構造多層骨組の進行性崩壊挙動 PROGRESSIVE COLLAPSE OF MULTI-STORY STEEL FRAMES
}

\author{
山崎真 司*1, 見波 進*2 \\ Shinji YAMAZAKI and Susumu MINAMI
}

\begin{abstract}
There are two cases of behavior of multistory frames after the vertical collapse of one story which occurs due to an event such as an explosion or an earthquake. One is where the collapse proceeds to a certain extent and then ceases and the other is where the collapse continuously progresses until all stories have completely collapsed. The collapse in the latter case is called progressive collapse which is an unstable phenomenon resulting from the gravity load of frames. This study clarified the frame conditions which enable stories to resist progressive collapse through comparing the gravity potential energy released by the story collapse with the energy which columns absorb before they completely collapse due to the compressive load.
\end{abstract}

Keywords : Potential energy, Strain energy, Frame stability, Multi-mass system, Numerical analysis 位置エネルギー, 歪エネルギー, 骨組の安定性, 多質点系, 数值解析

\section{1 序}

2001 年 9 月 11 日のニューヨーク世界貿易センタービル (WTC) の崩壊は, 局所的な層崩壊によって解放される重力エネルギーが契 機となり全層崩壊に至る可能性を知らしめた.

航空機の衝突により主架構に大きな欠損が生じたが直ちには崩 壊に至らず避難時間が確保され, 多くの在館者の退出を可能にし た.しかし衝突後に発生した大規模火災により鋼柱の温度が上昇し， WTC2 で衝突の約 1 時間後, WTC 1 で約 1 時間 40 分後に鉛直荷重 支持能力が失われたために上層部が落下し, これによって生じた運 動エネルギーを落下近傍層の柱の歪エネルギーで吸収できなかった ため順次崩壊が進行し全層崩壊に至った ${ }^{1)}$.

WTCの崩壊に関連して以下の研究が行われている.

航空機衝突時の挙動について, 福澤等 ${ }^{2)}$ は解析的検討を行い, 衝 突層の損傷状況および衝突後の航空機の挙動は解析で再現できるこ と, また衝突時に全体崩壊に至らなかったことが建物全体に対する 応答解析より推察できることを示している. 磯部等 ${ }^{374)}$ は航空機の 衝突に伴う骨組の崩壊過程を連続的に高精度で効率よく解析可能な 有限要素解析法を開発し, WTC2 の航空機衝突時の機体とエンジン の挙動および建物の損傷状況について解析結果と実現象は対応して いることを示している.

火災により柱の鉛直支持能力が失われ落下が生じた後の挙動につ いて Bažant 等 5) はエネルギーに基づく考察を行い，落下によって
解放される位置エネルギーに対し直下層の柱の塑性座屈によって吸 収できるエネルギーは楽観的な仮定に基づいて評価しても $1 / 8$ 以下 と見積られ, 直下層の崩壊によりさらに位置エネルギーが解放され るので崩壊が加速され，全体崩壊に至ったと述べている．大井等 6) は落下層の下部の柱が解放される位置エネルギーを塑性座屈変形に よって吸収しかつ座屈後の残存耐力で鉛直荷重を支持できることが 進行性崩壊を防止する条件であることを示し，大変形に至るまでの 座屈後挙動に関する部材実験を行い, 座屈後耐力について Bažant の モデルによる解と比較している，鈴木等 7)は質点系振動モデルを用 いて落下後の建物全体の挙動を調べ, 落下開始層における非弾性衝 突によるエネルギーの吸収は進行性崩壊を止めるほど有効ではない こと, 振動モデルにおける減衰の大きさが崩壊挙動に及ぼす影響が 大きいことを指摘している.

和田等 ${ }^{8)}$ はチューブ構造における外周架構と床梁構造との接合部 の破断による進行性崩壊について検討を行い, 進行性崩壊を防止す るための接合部の条件について考察している.

日本鋼構造協会「崩壊制御設計ガイドライン」9)では, 部材喪失に 対する構造骨組の挙動および火災加熱を受ける鋼架構の挙動に関す る研究に基づき, 鋼構造建築のリダンダンシーを定量的に評価する 手法および構造物のリダンタンシーを高める手法を提示している.

本論文は何らかの原因により鋼構造多層骨組のある層の鉛直荷重 支持能力が失われた後の骨組の挙動について考察し, 進行性崩壊を
*1 東京電機大学大学院理工学研究科 教授.工博

*2 首都大学東京大学院都市環境科学研究科建築学域 助教・博士 (工学)
Prof., Graduate School of Science and Engineering, Tokyo Denki University, Dr. Eng. Assistant Prof., Dept. of Architecture and Building Engineering, Graduate School of Urban Environmental Sciences, Tokyo Metropolitan University, Dr. Eng. 
防止するための条件を明らかにすることを目的とする．起点となる 層の崩壊は層の一部の柱材の耐力が消失するような場合ではなく, 当該層全体について鉛直荷重を支持することができなくなる場合 を対象とする，海外における地震においては，例えばメキシコ地震 (1985 年)の際のメキシコ市, トルコ・コジャエリ地震 (1999 年)の 際のイズミット等において見られるように, 多層建物が全層崩壊に 至る被害が生じているが，これらは進行性崩壊によるものと思われ る. 兵庫県南部地震 (1995 年) では複数の建物において中間層が完 全に崩壊する被害が発生したが進行性崩壊を生じた建物は無い.し かし，このことから耐震設計された我が国の建物においては進行性 崩壊が生じないと結論づけることは出来ないと思われる．鋼構造多 層建物について中間層崩壊した後の進行性崩壊の可能性について現 在のところ充分な検討が行われているとはいえない.

進行性崩壊は骨組の重力による不安定現象ととらえることができ る. 本論文では骨組の重力に対する安定性に関わる指標を導入する. 動的解析に基づき指標の有効性を検討し, 進行性崩壊を防止する条 件について考察する.

\section{2 検討対象モデル}

本論文では鋼構造多層骨組の任意の一層が, 地震, 火災, 爆破等 の要因により突然鉛直支持能力を失った後の骨組の挙動について考 察する.

層の鉛直支持能力が失われると当該層より上部の建物部分は落下 し, 当該層の床面に衝突する. その後の挙動は層の崩壊が局所で留 まり建物全体には広がらない場合と, 順次連鎖的に層崩壊が進行し 遂には建物全層の崩壊に至る場合とに大別される.

建物の条件とある層の鉛直支持能力が失われた後の挙動との関係 を検討するために本論文で用いるモデルの概要を以下に示す.

\section{a) 質点系モデル}

平面的に無限均等な架構を想定し, その中の 1 本の柱とその柱の 支配質量を取出し，図1(a)に示すように各階質量と柱材鉛直ばねか ら成る質点系モデルを考える．考慮する変位の自由度は鉛直方向の みとする. 何らかの原因により鉛直支持能力を失い落下する層 (以下 崩壊開始層) を第 $f$ 層とする. 崩壊開始層の鉛直方向の挙動は層崩 壊の要因や部材特性によって異なり種々の状態が考えられる，崩壊 開始層においては鉛直変位に伴うエネルギー吸収が無く層高さ分完 全に自由落下すると仮定すれば安全側となることから, 図 1(a)のよ うに静的に釣合った状態から同図 (b) のように第 $f$ 層の柱材を突然 取去った系を基本的な検討対象とする，なお，崩壊開始層における エネルギー吸収が骨組挙動に及ぼす影響については, 崩壊開始層に おける自由落下高さを変えることにより考察する.

\section{b) 一般層ばねの荷重変形関係}

柱材鉛直ばねの荷重変形関係は中心圧縮を受ける鋼柱の挙動 ${ }^{10)} に$ 基づき定める.

典型的な中心圧縮材の完全崩壊挙動は模式的に図 2 のように表わ される. 図の縦軸 $P$ と横軸 $x$ はそれぞれ鉛直方向荷重と鉛直方向 変位を表わす，通常の鋼構造多層建物に用いられている柱材の場合， $P$ が降伏荷重 $P_{y}$ に達すると曲げ座屈を生じ, 以降変位の増加とと もに耐力が低下する (細長比が極めて小さい場合は降伏後若干耐力が 上昇し，その後低下に転じる．），曲げられた材が折り重なるような
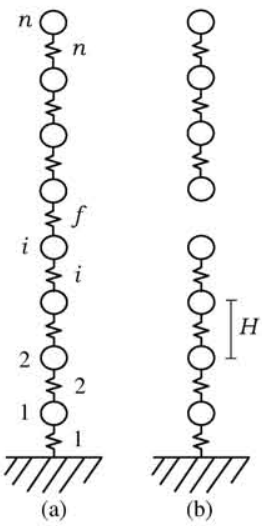

図1 質点系モデル

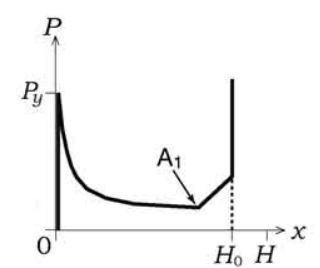

図 2 一般層ばねの荷重変形関係

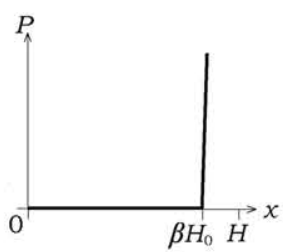

図 3 崩壊開始層ばねの荷重変形関係
大変形に達すると耐力が上昇し, 層の上下の床の間に挟まれた構造 部材が押しつぶされた状態に至ると極めて剛性が高くなる．図 2 の $H_{0}$ はそのような状態における変位量を示す.

\section{c) 崩壊開始層ばねの荷重変形関係}

崩壊開始層 (第 $f$ 層) の柱材を取去ることは, 第 $f$ 層のばねを図 2 のようなばねから図 3 のようなばねに瞬間的に変更することと等価 である.

落下開始以降のばねは衝突直前までは抵抗が無く衝突変位に達し た瞬間に極めて高い剛性を有するものとする. 衝突変位を $\beta H_{0}$ と し, 基本モデルにおいては $\beta$ を 1 とする. 自由落下高さの変化につ いては $0.5 \leq \beta \leq 1$ と想定し, 自由落下高さが応答に与える影響は, $\beta=0.5$ のモデルを用いて検討する.

d) 減衰

安全側の仮定として, 崩壊開始層において自由落下中の減衰おょ び衝突時のエネルギー吸収は無いものとする.

崩壞開始層以外の一般層においても, ばねの塑性仕事以外のエネ ルギー吸収は無いものとする.

\section{3 骨組の安定性に関する指標}

ここではエネルギーの釣合いから系の安定性について考察する. 2 に示したモデルについて, 崩壊開始層以外の任意の層において 層間鉛直変位により柱が吸収する歪エネルギーを考える，層間鉛直 変位 $x$ における吸収エネルギー $E(x)$ は次式で与えられる.

$$
E(x)=\int_{0}^{x} P(x) d x
$$

ところで, 当該層より上部の全質量を $M$ とすると, 当該層の変 形 $x$ により $\operatorname{Mg} x$ (ここで $g$ : 重力加速度) の位置エネルギーが解放さ れ, 解放されたエネルギーは構造物に入力する. 従って次式による $E_{r}(x)$ を変位 $x$ における有効吸収エネルギーとする.

$$
E_{r}(x)=E(x)-M g x
$$

図 4(a) に実線で示すような層の荷重変形関係に対し, $M g$ が図 中に(1)〜 (3)で示す 3 種類のレベルであるとしたとき, 吸収エネル ギー $E(x)$ と $M g x$ を求めると, 図 4(b) の実線および破線のように なる．このときの有効吸収エネルギー $E r(x)$ は図 4(c) の実線のよう になる.

(1)の場合は $E_{r}(x)$ は常に増加関数であるが, (2), (3)の場合は $P<M g$ を満たす $x$ の範囲で $E_{r}(x)$ は減少関数となり, また(3)の場 
合はある值以上の $x$ に対して $E_{r}(x)$ の值が負である.

$x$ が $H_{0}$ のときの $E_{r}(x)$ の值を $E_{r 0}$ とし, 有効エネルギー吸収率 $\alpha$ を次式で定義する.

$$
\alpha=\frac{E_{r 0}}{M g H_{0}}
$$

また, 柱の $0 \leq x \leq H_{0}$ における抵抗力の平均值を平均耐力 $P_{a}$ と する.

$$
P_{a}=\frac{\int_{0}^{H_{0}} P(x) d x}{H_{0}}
$$

図 4(a) の荷重変形関係における $P_{a}$ の大きさを同図中に一点鎖線 で示す. 式 (2)で $x=H_{0}$ のとき

$$
E_{r 0}=P_{a} H_{0}-M g H_{0}
$$

であるから， $\alpha$ は次式で表される.

$$
\alpha=\frac{P_{a}}{M g}-1
$$

$\alpha$ は系の重力に対する安定性に関し基本的な指標であると考える ことができる，例えば $\alpha>\beta$ の骨組の場合は，崩壊開始層の落下に より解放される位置エネルギーをその近傍の一つの層で吸収するこ とができるので層の崩壊が連鎖的に進行することは無い， $\alpha<0$ の 骨組の場合は $x$ が $H_{0}$ のときの有効吸収エネルギーが負すなわち当 該層の崩壊によりエネルギーが放出されることになるので，進行性 崩壊に至る可能性が高い. $\alpha$ と崩壊性状の関係については 4 におい て振動解析に基づき検討する。

\section{4 動的解析}

\section{1 解析法}

\subsection{1 振動系}

まず落下開始前の釣合い状態を図 1(a)のモデルを用いて求める. すべての層のばねを図 2 に示すような特性とし, 重力加速度を外力 とし粘性滅衰を考慮して解析を行う。充分な時間が経過し系が静的 な釣合い状態に至った後, 崩壊開始層 (第 $f$ 層)のみバネを図 3 に示 すような特性に置き換え, 同時に粘性減衰を無しとし, 落下開始後 の挙動に対する解析を行う.

\subsection{2 衝突の扱い}

崩壊開始層における衝突は一般に完全弾性衝突と完全非弾性衝突 との中間にあると考えられるが, 本解析ではエネルギー吸収の点で 安全側である完全弾性衝突と仮定する。 なぜなら, 衝突により吸収 するエネルギーの衝突直前の運動エネルギーに対する比は比較的小 さい場合が多いと考えられる注11) からである.

図 5 に示す崩壊開始層の復元力特性モデルにおいて, $x \geq \beta H_{0}$ に おける剛性 $K_{1}$ は充分大きいことが望ましい. 解析精度と数值計算

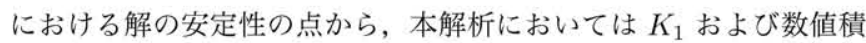
分における時間間隔 $\Delta t$ は次式を満たす值とした 注2).

$$
\begin{aligned}
K_{1} & \geq(100 \pi)^{2} \frac{m_{f} g}{2 \beta H_{0}} \\
\Delta t & \leq \frac{\pi}{20} \sqrt{\frac{m_{f}}{K_{1}}}
\end{aligned}
$$

ここで $m_{f}:$ 衝突する質点の質量

また, 崩壊開始層ばねの力と変位は常に図 5 に示す太実線上を移 動することとし，このばねによるエネルギー吸収は無いものとする.

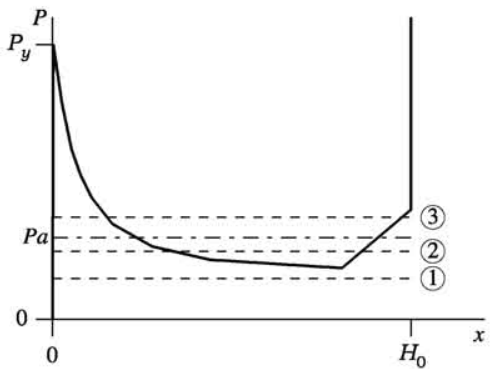

(a) 層の荷重変形関係と $M g$ の大きさ

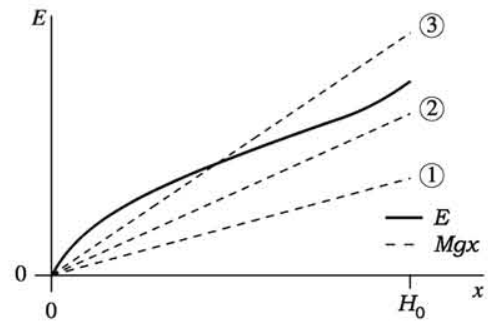

(b) 吸収エネルギーEと $M g x$

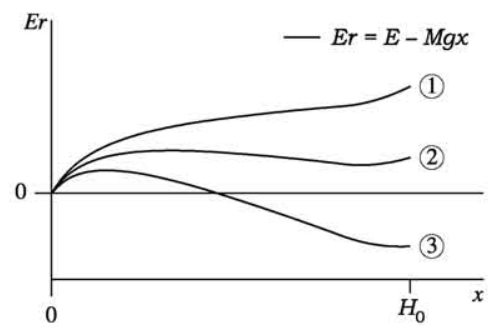

(c) 有効吸収エネルギー $E_{r}$

図 4 層の荷重変形関係と有効吸収エネルギー
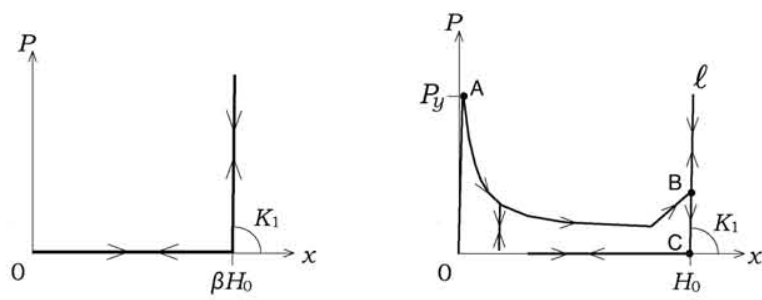

図 5 崩壊開始層の履歷特性モデル

図 6 一般層ばねの履歴特性モデル

\subsection{3一般層ばねの履歴特性}

一般層ばねの履歴特性モデルを図 6 に示す．図中の A から B ま での区間においては負方向の変位に対しては弾性除荷し, B 点に達 した後は $\mathrm{B}$ 点を通り $\mathrm{C}$ を起点とする半直線 $\ell$ と直線 $\mathrm{OC}$ 上を移動す る履歴とする，直線 $\ell$ の勾配は式 (7) を満たすように定める．B 点 に至るまでは歪エネルギーを吸収し， B 点に達した以降は歪エネル ギーを吸収しない.

\section{2 骨組モデル}

解析に用いる骨組モデルは次の 3 種類とする.

骨組 A：均等な特性の 30 層骨組

骨組 B：連続する 3 層 (ただし最上部は 6 層) は同一断面とする 不均等な特性の 30 層骨組

骨組 C：実建物骨組を参考に設定した骨組 B より不均等性の高 い37 層骨組

各骨組の基本的な特性を図 7 にまとめて示す，図中の記号はそれ ぞれ以下を表す。

$m_{i}: i$ 質点の質量, $\bar{m}: m_{i}$ の平均值, 


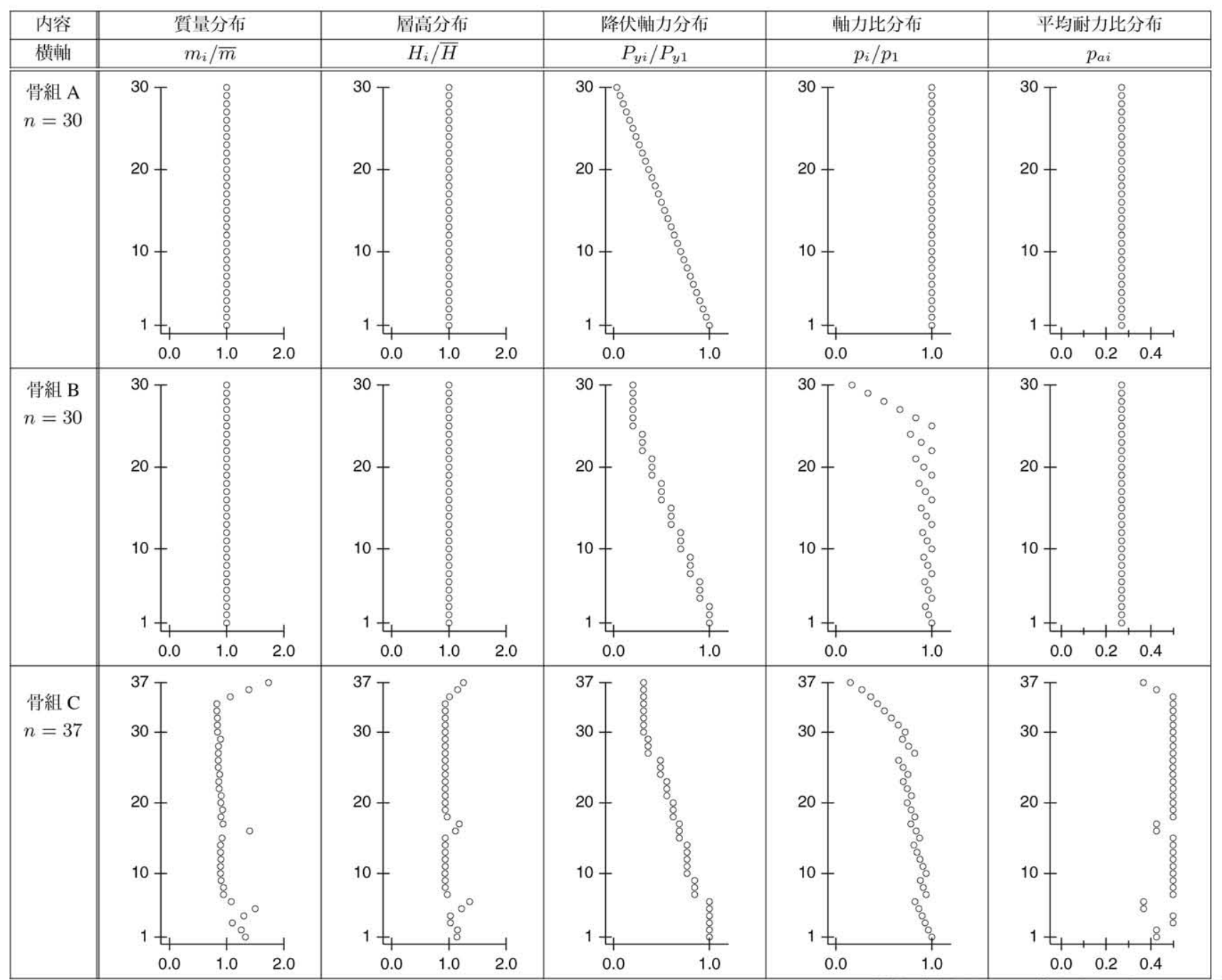

図 7 各骨組の構造特性

$H_{i}: i$ 層の層高さ, $\bar{H}: H_{i}$ の平均值,

$p_{i}=\frac{M_{i} g}{P_{y i}}: i$ 層ばねの軸力比, $\quad P_{y i}: i$ 層ばねの降伏軸力,

$M_{i}=\sum_{j=i}^{n} m_{j}: i$ 質点より上部の全質量,

$p_{a i}=\frac{P_{a i}}{P_{y i}}: i$ 層ばねの平均耐力比

$P_{a i}: i$ 層ばねの平均耐力 (式 (4))

各骨組に用いるばねの特性を図 8 に示す。図 8 において荷重およ び変位はそれぞれ降伏軸力および層高で除し基準化した表現として いる，骨組 A, 骨組 B のばね特性はすべて図 8(a) とし，骨組 C のば ね特性は図 8(b) の $\mathrm{c} 1 \sim \mathrm{c} 3$ の 3 種類とした。骨組 C の各層ばね特性 を表 1 に示す。これらのばね特性は骨組 A, 骨組 B については柱の 細長比を $\lambda_{c}=0.2$ 程度, 骨組 C については $\lambda_{c}=0.1 \sim 0.14$ 程度と 想定し, 文献 10)の実験結果を参考に設定した。ここで, $\lambda_{c}$ は次式 による基準化細長比である.

$$
\lambda_{c}=\frac{L}{i} \frac{\sqrt{\sigma_{y} / E}}{\pi}
$$

$L$ : 座屈長さ, $i$ : 断面 2 次半径, $\sigma_{y}$ : 降伏応力, $E$ : ヤング率

骨組 Aのように, 各質点の質量, 各層高さ, 軸力比がそれぞれ等 しく, また, 基準化した各層ばねの特性が等しい骨組を, 均等骨組 とし, 本論文における進行性崩壊挙動の検討は主に均等骨組を対象
に行う、現実の骨組は均等骨組ではないが均等骨組からの変動は通 常あまり大きくないと考えられるので, 骨組 B, 骨組 C モデルを用 いて現実的な不均等性を有する骨組 (ほぼ均等な骨組) に対する考察 を行うこととする.

各骨組について崩壊開始層位置および質量の大きさを変えて (た だし質量の分布形は変えない) 解析を行い. 崩壊性状について考察 する.

質量の大きさに応じて各層の有効エネルギー吸収率 $\alpha$ が定まる. 骨組 A では各層の $\alpha$ は等しく, それを解析モデルの有効エネルギー 吸収率 $\alpha_{m}$ とする，骨組 B，C については各層の $\alpha$ は同一ではない ので, 崩壊開始層の上下のそれぞれ 2 層計 4 層の $\alpha$ の平均值を解析 モデルの有効エネルギー吸収率 $\alpha_{m}$ とする. (ただし崩壊開始層が最 下層の場合は上 2 層の平均値を $\alpha_{m}$ とする.)

解析骨組条件の一覧を表 2 に示す．各解析ケースは次のように表 示する.

骨組 $(\beta)$ - 崩壊開始層 $\left(\alpha_{m}\right)$

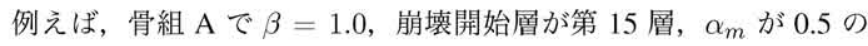
とき,

$$
\mathrm{A}(1.0)-15(0.5)
$$

と表す. 


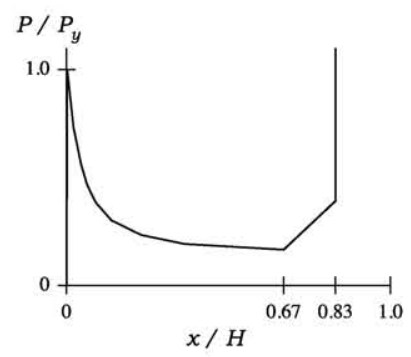

(a) 骨組 A, 骨組 B

表 1 骨組 C の各層ばね特性 層番号

\begin{tabular}{c|c}
\hline 37 & $\mathrm{c} 3$ \\
36 & $\mathrm{c} 2$ \\
35 & $\mathrm{c} 1$ \\
34 & $\mathrm{c} 1$ \\
$\vdots$ & $\vdots$ \\
19 & $\mathrm{c} 1$ \\
18 & $\mathrm{c} 1$ \\
17 & $\mathrm{c} 2$ \\
16 & $\mathrm{c} 2$ \\
15 & $\mathrm{c} 1$ \\
14 & $\mathrm{c} 1$ \\
$\vdots$ & $\vdots$ \\
8 & $\mathrm{c} 1$ \\
7 & $\mathrm{c} 1$ \\
6 & $\mathrm{c} 3$ \\
5 & $\mathrm{c} 3$ \\
4 & $\mathrm{c} 1$ \\
3 & $\mathrm{cl}$ \\
2 & $\mathrm{c} 2$ \\
1 & $\mathrm{c} 2$ \\
\hline
\end{tabular}

\section{3 解析結果}

\subsection{1 $\beta=1$ のモデルに対する解析結果}

骨組 $\mathrm{A}$ について崩壞開始層を第 15 層とした場合の解析結果の一 部を図9～図 11 に示す。各図において, (a) は質点変位の時刻歴を, (b) はエネルギーの時刻歴を表している，(b)における実線は解放さ れる重力位置エネルギーの大きさを，破線と一点鎖線はそれぞれ歪 エネルギーおよび運動エネルギーの大きさを示している。 (c) は層の 崩壊時刻 (変位が荷重変形関係の極小値 (図 2 の $\mathrm{A}_{1}$ 点) に達した時を 崩壊とする。)をプロットしたものである。・印は崩壞開始層を。印 はその他の層を示している，なお，時刻は崩壊開始層における落下 開始時を起点とした。また，(b)におけるエネルギーの大きさは次式 による $E_{0}$ で除して無次元化している.

$$
E_{0}=\sum_{i=1}^{n} M_{i} g H_{0 i} \quad\left(H_{0 i}: i \text { 層の可動高さ }\right)
$$

$\alpha_{m}=0$ (図 9) の場合は崩壊開始層から上下層方向に順次崩壊が准 行し全層崩壞に至っている。 ただし最下部 2 層と最上部 3 層では崩 壊進行の順序が逆転している。 $\alpha_{m}=0.1$ (図 10) の場合も崩壊開始 層から上層下層方向に崩壊が拡大しているが，全体で 9 層の崩壊に 止まっている (崩壊層数には崩壊開始層も含む)。 $\alpha_{m}=0.5$ (図 11) の場合は崩壊開始層の直上層の崩壊で進行が止まっている.

骨組 B について崩壊開始層を第 14 層とした場合の解析結果の一 部を図 12, 図 13 に示す。層崩壊挙動は全体としてA-15 の場合に類 似している，骨組 B では連続する 3 層 (ただし最上部は 6 層)を同一 の柱断面としており，同一断面材を用いている最下層が相対的に耐 力が低い層となっている(図 7). 図 12, 図 13 の (c) において相対的 に耐力が低い層のプロットに一印を付している，相対的に耐力が低 い層が崩壊し易い傾向が見られる。
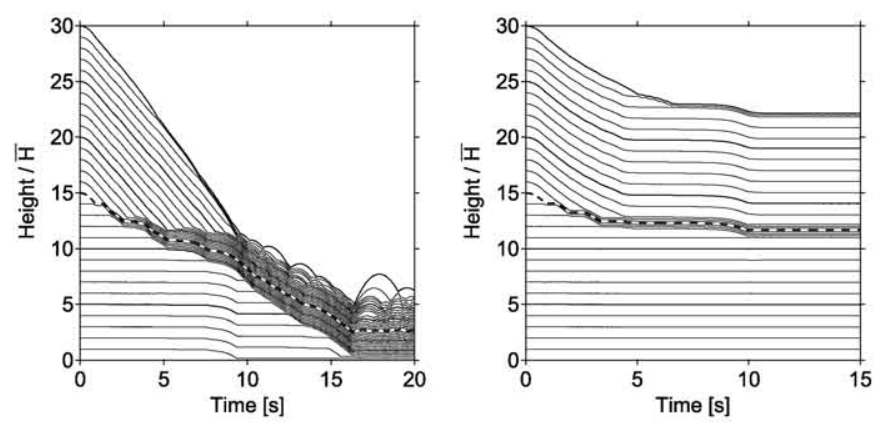

(a) 変位

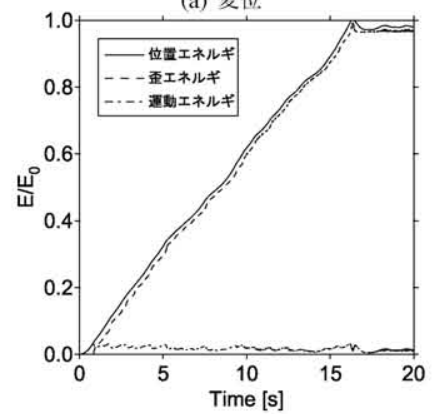

(a) 変位

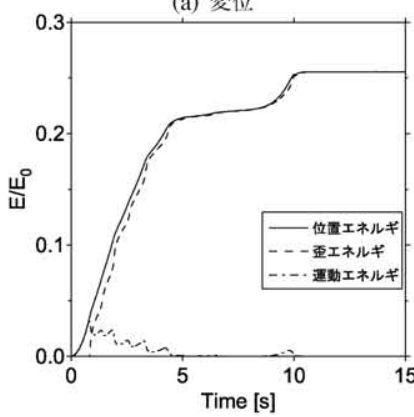

(b) エネルギー

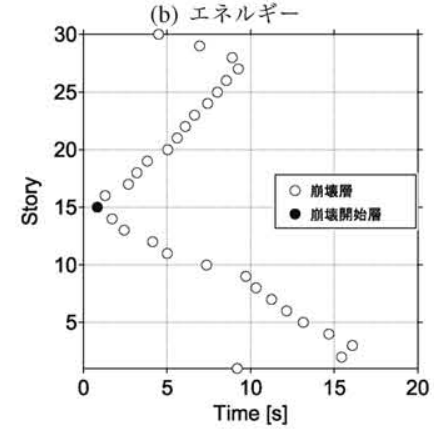

(c) 崩溒層

図 $9 \mathrm{~A}(1.0)-15(0.0)$ 時刻歷

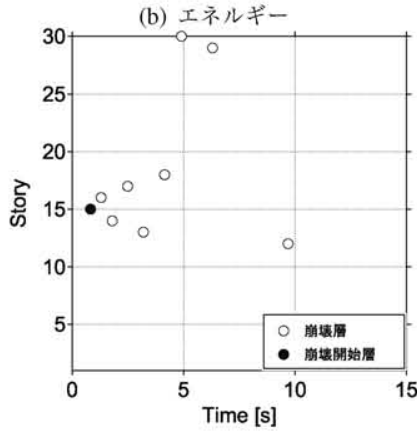

(c) 崩壊原
骨組 C について崩壊開始層を第 20 層とした場合の解析結果の一 部を図 14, 図 15 に示す。図 12, 図 13 と同様に相対的に耐力が低 い層のプロットに一印を付している，骨組 B の場合と同様に相対的 に耐力が低い層が崩壊し易い傾向が見られる.

\subsection{2 $\beta \neq 1$ のモデルに対する解析結果}

骨組 $\mathrm{A}, \beta=0.5$ で崩壊開始層を第 15 層とした場合の解析結果の 一部を図 16, 図 17 に示す。それぞれを図 9, 図 10 と比較すると, 崩壊性状は類似しているが，同一の $\alpha_{m}$ に対して $\beta$ が小さい方が崩 壊開始層の自由落下により解放される位置エネルギーが小さいため, 崩壊層数が少ないことが分かる.

\section{4 解析結果に対する考察}

\subsection{1 エネルギーの釣合に基づく崩壊層数の予測}

均等骨組を対象として有効エネルギー吸収率 $\alpha$ と崩壊層数 $n_{c}$ (崩 壊層数には崩壊開始層も含む)の関係について考える.

i) $\alpha>\beta$ の場合

崩壊開始層の落下により解放される位置エネルギーを崩壊開始層 に接する一つの層で吸収可能であるので, $n_{c}=1$ である.

ii) $0 \leq \alpha \leq \beta$ の場合

エネルギーの釣合により，次式が成り立つ。

$\left(n_{c}-1\right) \bar{E}_{r 0}+E_{a}=\beta\left(M g H_{0}\right)_{f}$ 

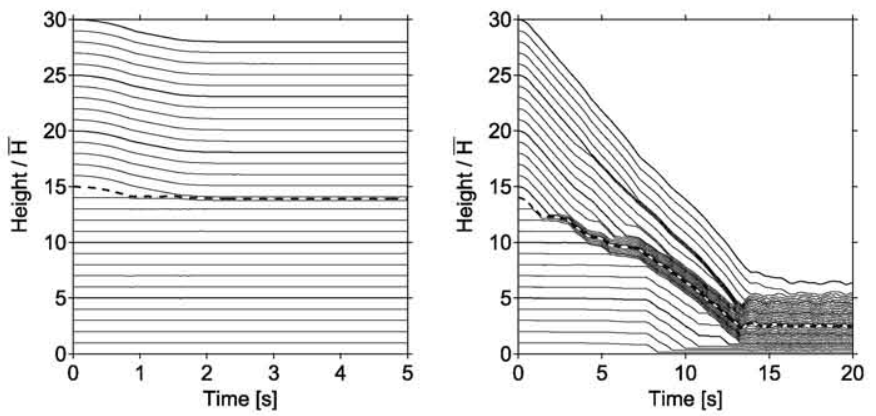

(a) 変位

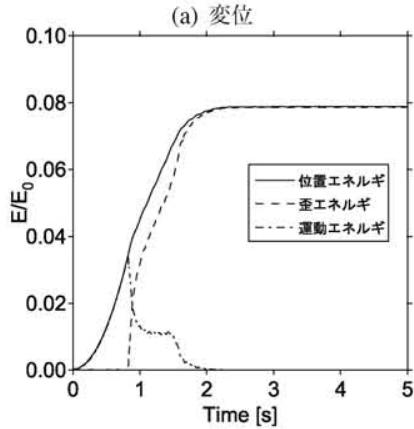

(b) エネルギー

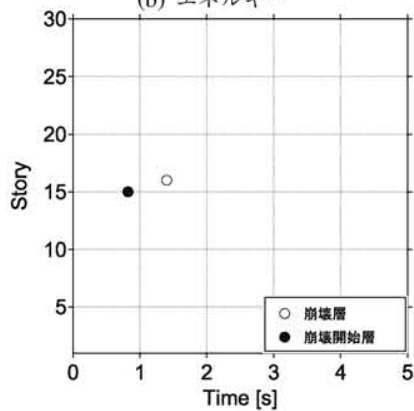

(c) 崩馌層

図 $11 \mathrm{~A}(1.0)-15(0.5)$ 時刻歴

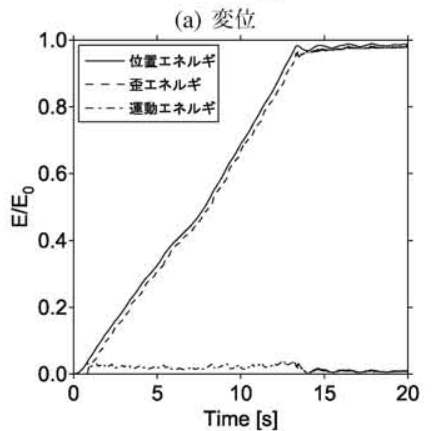

(b) エネルギー

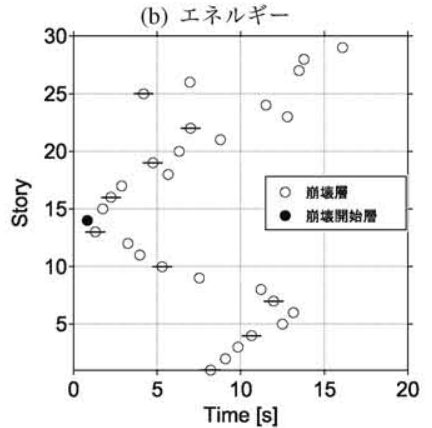

(c) 崩壊層

図 $12 \mathrm{~B}(1.0)-14(0.0)$ 侍刻歴

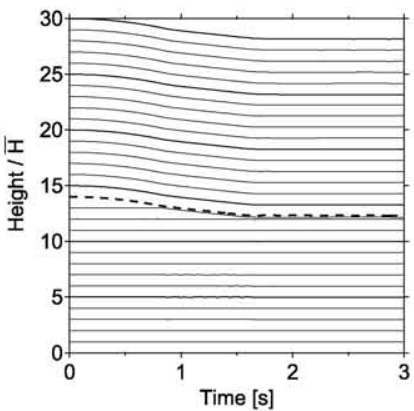

(a) 変位

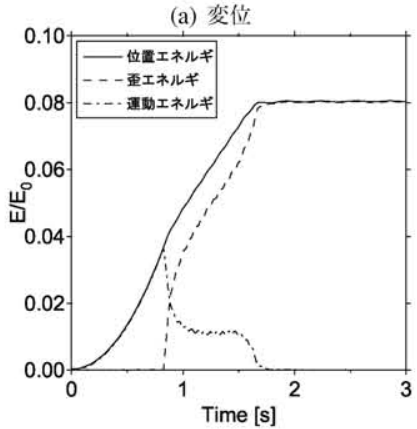

(b) エネルギー

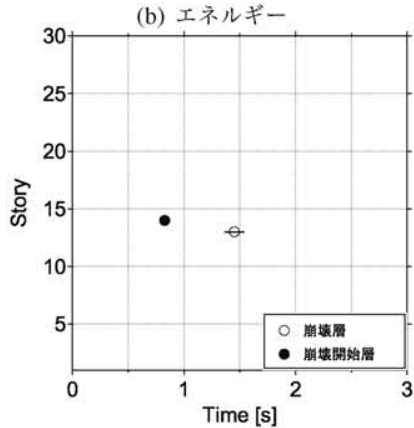

(c) 崩壊層

図 $13 \mathrm{~B}(1.0)-14(0.59)$ 時刻歴

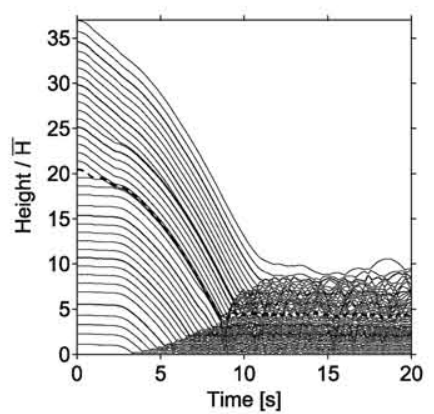

(a) 変位

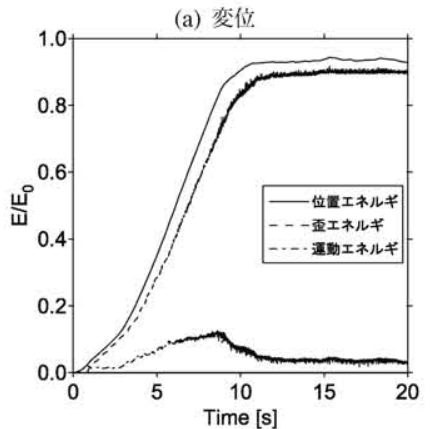

(b) エネルギー

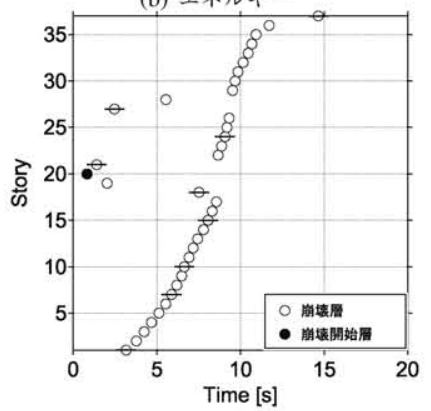

(c) 前壇層

図 $14 \quad C(1.0)-20(0.01)$ 時刻歴

$\bar{E}_{r 0}$ : 崩壊開始層以外の崩壊層における有効吸収エネルギーの 1 層 あたり平均值

$E_{a}:$ 崩壊に至らない層で吸収するエネルギー

$\beta\left(M g H_{0}\right)_{f}$ : 崩壊開始層の落下により解放される位置エネルギー 式(10)より

$$
\begin{aligned}
n_{c} & =\frac{\beta\left(M g H_{0}\right)_{f}}{\bar{E}_{r 0}}-\frac{E_{a}}{\bar{E}_{r 0}}+1 \\
& =\frac{\beta\left(M g H_{0}\right)_{f}}{\left(E_{r 0}\right)_{f}} \cdot \frac{\left(E_{r 0}\right)_{f}}{\bar{E}_{r 0}}-\frac{E_{a}}{\bar{E}_{r 0}}+1
\end{aligned}
$$

ここで,

$\left(E_{r 0}\right)_{f}$ : 第 $f$ 層が崩壊開始層でない場合の第 $f$ 層による有効吸収

$$
\text { エネルギー }
$$

近似的に $\frac{\left(E_{r 0}\right)_{f}}{\bar{E}_{r 0}}$ を 1 , 安全側に $\frac{E_{a}}{\bar{E}_{r 0}}$ を 0 とすれば, $\frac{\left(M g H_{0}\right)_{f}}{\left(E_{r 0}\right)_{f}}=\frac{1}{\alpha}$ であるから, 式(11)より次の近似式が得られる.

$$
n_{c}=\frac{\beta}{\alpha}+1 \quad\left(\text { ただし } n_{c} \leq n\right)
$$

なお, $\frac{\left(E_{r 0}\right)_{f}}{\bar{E}_{r 0}}$ を 1 と近似することは, 崩壊開始層が中央付近の層で あれば妥当であるが, 最上層に近い場合は $\bar{E}_{r 0}>\left(E_{r 0}\right)_{f}$ であるの で安全側, 最下層に使い場合は $\bar{E}_{r 0}<\left(E_{r 0}\right)_{f}$ であるから危険側の 近似である.

\section{iii) $\alpha<0$ の場合}

$\alpha<0$ の場合は層崩壞によってエネルギーが供給される系なので, 一般に進行性崩壊に至ると考えられる。ただし， $\alpha<0$ の場合にお いても式 (13) を満たせば崩壊開始層の落下によって解放されるエネ ルギーをその直上層で吸収可能であるので $n_{c}$ は 1 である.

$$
\left(E_{2}\right)_{f+1} \geq \beta\left(M g H_{0}\right)_{f}
$$

ここで,

$\left(E_{2}\right)_{f+1}$ : 崩壊開始層の直下層において, 軸力 $P$ が最大荷重から耐 力劣化後 $M g$ に達するまでの有効吸収エネルギー (図 18 斜線部 の面積)

層の荷重変形関係を文献 10) に基づき設定した場合， $0.5 \leq \beta \leq 1$ に対して式(13) は成立しない. 従って, $\alpha<0$ の場合は進行性崩壊 に至り $n_{c}=n$ である.

現実的な不均等性を考慮した骨組の場合においても近似的に均等 骨組と同様な関係が成立するとすれば，上述の諸式の $\alpha$ を $\alpha_{m}$ と置 き,ほぼ均等な骨組について崩壊層数 $n_{c}$ に関する以下の予測式が得 られる。

$$
\left.\begin{array}{lrl}
\alpha_{m}>\beta & \text { の場合 } & n_{c}=1 \\
0 \leq \alpha_{m} \leq \beta \text { の場合 } & n_{c}=\frac{\beta}{\alpha_{m}}+1 \quad\left(\text { ただし } n_{c} \leq n\right) \\
\alpha_{m}<0 & \text { の場合 } & n_{c}=n
\end{array}\right\}
$$




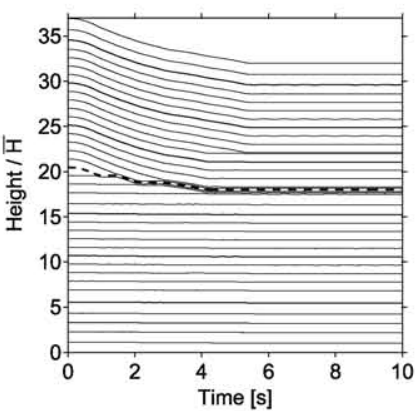

(a) 変位

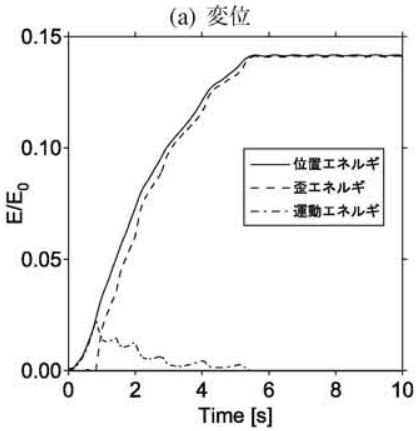

(b) エネルギー

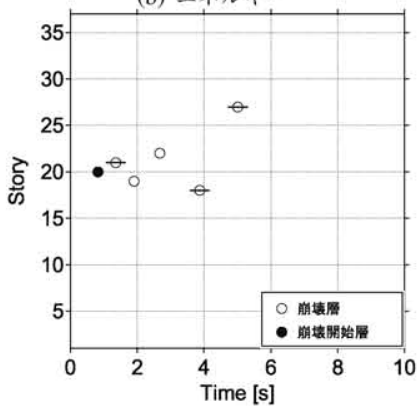

(c) 崩溒層

図 $15 \mathrm{C}(1.0)-20(0.14)$ 時刻歴

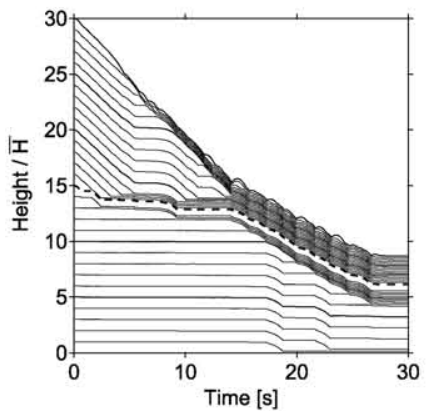

(a) 変位

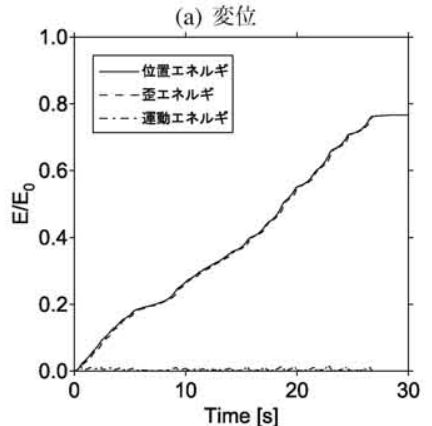

(b) エネルギー

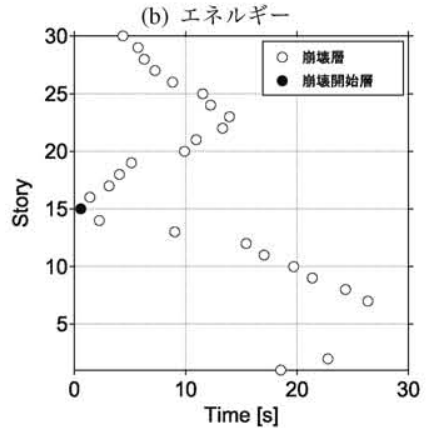

(c) 崩壊層

図 $16 \mathrm{~A}(0.5)-15(0.0)$ 時刻歴

\subsection{2 崩壊層数に関する予測値と数値解析結果の比較}

表 2 に示した解析条件に対して, モデルの有効エネルギー吸収 率 $\alpha_{m}$ と数值解析から得られた崩壊層数 $n_{c}$ の関係を図 19 に示す. 同図に式 (14)による $\alpha_{m}$ と $n_{c}$ の関係を, $\beta=1$ の場合を実線で, $\beta=0.5$ の場合を破線で示す. 崩壊層数は式 (14)により概ね予測で きることが分かる.

\section{5 柱の条件と骨組の安定性}

4 の検討により, ほぼ均等な鋼構造多層骨組において, 任意の 1 層 が鉛直支持能力を失った後の骨組の安定性に関わる指標として有効 エネルギー吸収率 $\alpha$ が有効であることがわかった，骨組モデルの有 効エネルギー吸収率 $\alpha_{m}$ と層崩壊後の骨組挙動との関係は図 19 上 り次のように整理される.

$\alpha_{m} \geq 0.5$ の場合

崩壊層数は崩壊開始層を含めても 1 2 程度であり, 進行性崩壊 を生じない

$\alpha_{m} \leq 0$ の場合

骨組は不安定であり, 進行性崩壊に至る.

$0<\alpha_{m}<0.5$ の場合

数層から数 10 層の崩壊が生じる．崩壊層数は式 (14)により概 ね予測できる。

文献 10) による箱形断面材の中心圧縮挙動に基づき, 柱材の細長比

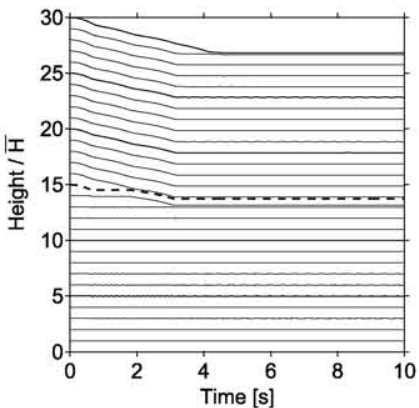

(a) 変位

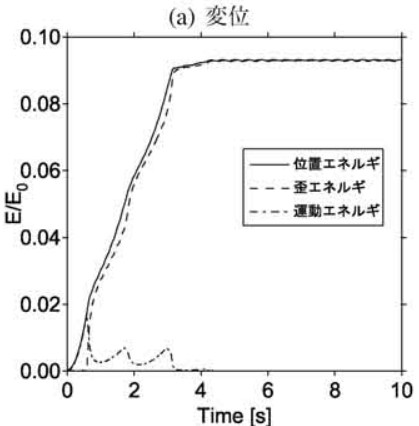

(b) エネルギー

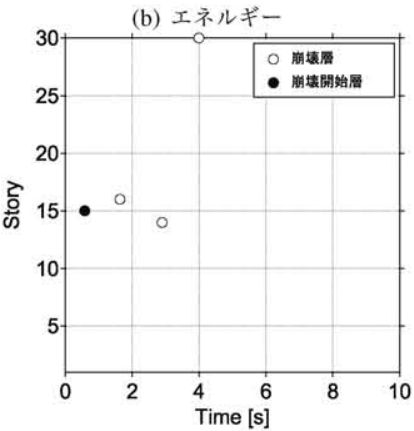

(c) 崩填層

図 $17 \mathrm{~A}(0.5)-15(0.1)$ 時刻歴

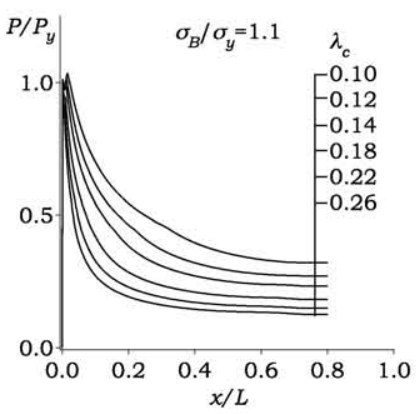

図 20 箱形断面鎙柱の挙動

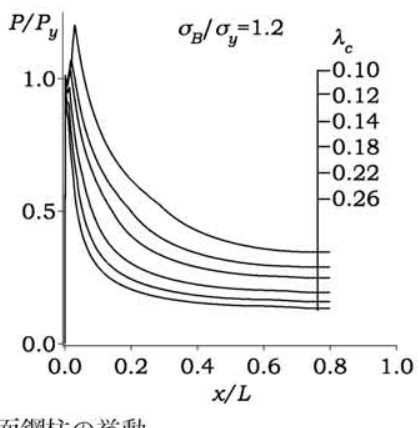

$f=20 \quad(\beta=1)$

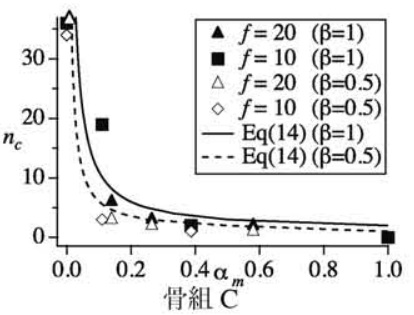

図 $19 \alpha_{m}$ と崩壊層数の関係 と骨組の安定性の関係について考察する. 鋼材の応力歪関係は平均
的な $490 \mathrm{~N} / \mathrm{mm}^{2}$ 級鋼材の特性 ${ }^{11)}$ (降伏応力 $\sigma_{y}=371 \mathrm{~N} / \mathrm{mm}^{2}$ ) とする. 短柱圧縮試験による最大応力 $\sigma_{B}$ と降伏応力 $\sigma_{y}$ の比 (応力上昇率) が 1.1 と 1.2 の場合について中心圧縮柱の荷重変形関係を図 20 に示 す. 図の縦軸, 横軸はそれぞれ降伏軸力および座屈長さ $L て ゙$ 除して 無次元化している.ここでは, 安全側の評価として折曲った部材同 士の接触による耐力上昇は無視している.

図 20 の荷重変形関係より細長比 $\left(\lambda_{c}\right)$ と平均耐力比 $\left(p_{a}=P_{a} / P_{y}\right)$ の関係を求め, 結果を図 21 に示す. (ここで, $p_{a}$ は $x / L$ が 0 から 0.75 までの範囲の $P / P_{y}$ の平均值とした， ) また, 図 21 に基づき, 有効エネルギー吸収率 $\alpha$ が 0 と 0.5 の場合について細長比 $\left(\lambda_{c}\right)$ と軸 


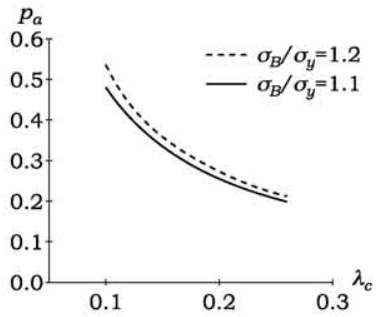

図 21 細長比と平均耐力比の関係

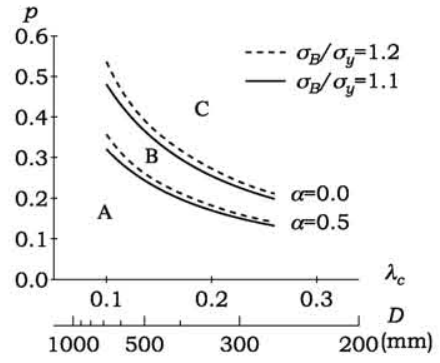

図22 $\alpha$ が 0 と 0.5 のときの軸 力比と紼長比の関係

力比 $\left(p=P / P_{y}\right)$ の関係を求め, 図 22 に示す. (ここで, $\alpha=p_{a} / p-1$ の関係を用いた） )図 21 , 図 22 において $\sigma_{B} / \sigma_{y}$ が 1.1 の場合を実線で, 1.2 の場合を破線で表している.

図 22 において, 細長比と軸力比の組合せが,

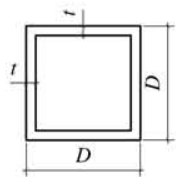

図 23 柱断面 $\alpha=0.0$ および $\alpha=0.5$ の曲線によって図中に

A，B，Cで示す 3 領域に分けられる. 骨組を構成する平均的な柱に 関する細長比と軸力比の組合せが領域 A であれば進行性崩壊を生じ ない, 領域 Cであれば進行性崩壊を生じる可能性がある, 領域 B で あれば複数層の崩壊が生じる可能性があると推定される.

例として, 柱の鋼材が $490 \mathrm{~N} / \mathrm{mm}^{2}$ 級, 断面が等幅等厚箱形 (図 23), 階高が $4 \mathrm{~m}$ のとき, 柱の曲げ座屈長さを $2 \mathrm{~m}$ と仮定すれば注 3$)$, 次の 近似式が得られる注4).

$$
\lambda_{c}=\frac{68}{D} \quad D: \text { 断面幅 }(\mathrm{mm})
$$

図 22 の横軸に式 (15) によるDの值を示した。本図により, 柱断 面寸法と鉛直荷重時の軸力比に基づき骨組の安定性に関する概略の 検討が可能である.

なお，本方法をWTC に適用し， $\alpha$ を過大に評価する仮定の下で $\alpha$ の概算值を求めると負の值となることから (付録 1 参照), 本方法に より進行性崩壊に至る可能性を有する骨組であることが推測される.

\section{6 結論}

本論文では鋼構造多層骨組の任意の 1 層が何らかの原因により突 然鉛直支持能力を失った後の骨組の挙動について考察した，得られ た結論は以下のように要約される.

1) 進行性崩壊挙動に関する指標として有効エネルギー吸収率を導入 した.

2) 均等な骨組モデルおよび現実的な不均等性を有する骨組モデルを 用いて, 任意の 1 層が崩壊した後の挙動に関する数值解析を行い, この指標の有効性を確認した。

3) 純ラーメン架構を対象として, 骨組を構成する平均的な柱の細長 比と軸力比を用い, 進行性崩壊の可能性について概略の検討を行 う方法を示した。

層の鉛直変位に伴うエネルギー吸収は主に柱材によってなされる ことから, 本論文では柱材のみを対象とした簡易なモデルを用いて, 進行性崩壊挙動について考察した。梁部材の影響に関する検討は今 後の課題とする.

\section{謝辞}

本研究の一部は H17-18 年度学術振興会科学研究費補助金 (基盤研 究 (C) 課題番号:17560514 研究代表者:見波進)の補助を受けた. 記 してここに謝意を表する.

\section{注}

注1) 簡単なモデルを用いて, 完全非弾性衝突と仮定したときのエネルギー 吸收量について考察する。

質点数を $n$, 崩壊開始層を第 $f$ 層とし, 各質点の質量はすべて同一で $m$ とする (本文図 1 参照)，衝突直前の質点 $f$ の速度を $v_{0}$ とすれば，完 全非弾性衝突直後の質点 $f$ および $f-1$ の速度 $v_{a}$ は運動量保存の法則 により次式で与えられる.

$$
v_{a}=\frac{1}{2} v_{0}
$$

衝突直前および直後の系の運動エネルギーを $E_{0}, E_{a}$ とすれば,

$$
E_{0}=\frac{1}{2}(n-f+1) m v_{0}^{2}, \quad E_{a}=\frac{1}{2}(n-f) m v_{0}^{2}+\frac{1}{2} \cdot 2 m v_{a}^{2}
$$

であるから，完全非弾性衝突によって吸収するエネルギーを衝突直前の 運動エネルギーで除した值は

$$
\frac{E_{0}-E_{a}}{E_{0}}=\frac{1}{2(n-f+1)}
$$

である. 例えば崩壊開始層より上部の層数が 10 であればこの值は $1 / 22$ であり, 非弹性衝突により吸収するエネルギーの衝突直前の運動エネル ギーに対する比は比較的小さい場合が多いと考えられる.

注2) 図注1に示すように質点 $m$ の物体が高さ $\beta H_{0}$ から自由落下し床に完 全弾性衝突する現象を, 図注2 2 に示すような振動モデルで数值計算を行う 場合を考える。ここで，図注2 2 ばねの復元力特性は図注3に示すようで あるとする。

自由落下時間を $t_{0}$, ばねに反力が生じている時間を $t_{1}$ とすれば，それ ぞれ次式で与えられる。

$$
t_{0}=\sqrt{2 \frac{\beta H_{0}}{g}}, \quad t_{1}=\pi \sqrt{\frac{m_{f}}{K_{1}}}
$$

解析精度を確保するために $\frac{t_{1}}{t_{0}} \leq \frac{1}{100}$ を满たすように $K_{1}$ を定めるこ ととすれば, 次の条件式が得られる.

$$
K_{1} \geq(100 \pi)^{2} \frac{m_{f} g}{2 \beta H_{0}}
$$

数值積分における時間間隔 $\Delta t$ は次式を満足するように設定する。

$$
\Delta t \leq \frac{t_{1}}{20}=\frac{\pi}{20} \sqrt{\frac{m_{f}}{K_{1}}}
$$

式 (注1)，(注2)の等号が成立つときのモデルに対する数估解析結果と 理論解を比較し，充分な解析精度が得られることを確認した。

注3) 剛接骨組中の柱の塑性曲げ座屈時には雨端と材中央の 3 筒所に塑性七 ンジが生じると予想されるので, 座屈長さは近似的に層高さの $1 / 2$ として よいと考えられる. 座屈長さについての詳紼な検討は今後の課題とする. 注4)

$$
\lambda_{c}=\frac{L}{i} \frac{\sqrt{\sigma_{y} / E}}{\pi}
$$

上式に, $L=2000 \mathrm{~mm}, i=0.4 D, \sigma_{y}=371 \mathrm{~N} / \mathrm{mm}^{2}, E=2.05 \times$ $10^{5} \mathrm{~N} / \mathrm{mm}^{2}$ を代人すると次式が得られる,

$$
\lambda_{c}=\frac{68}{D}
$$

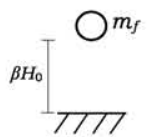

図注

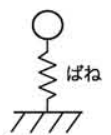

図注2

数值解析モ デル

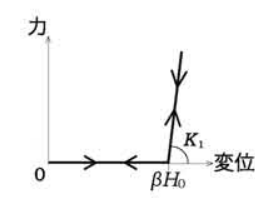

図注3ばねの復元力特性 


\section{参考文献}

1) 日本建築学会 WTC 崩壊特別調査委員会: 世界貿易センタービル崩壊特 別調查委員会報告書 - WTC 崩壊・ペンタゴンの被害・教訓 - , 日本建 築学会大会 PD 資料, 2003.9

2) 福田隆介, 福澤栄治, 小麇紀英, 森川博司: ニューヨーク世界貿易セン

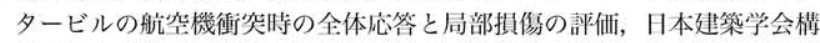
造系論文集，No.570，pp. 77-84，2003.8

3) 磯部大吾郎, リンチョウミョウ: 飛行機の衝突に伴う骨組鋼構造の崩壊 解析, 日本建築学会構造系論文集, No.579, pp. 39-46, 2004.5

4) 磯部人吾郎, リンチョウミョウ: ASI-Gauss 法による世界貿易センター ビルの飛行機衝突解析, 日本建築学会構造系論文集, No.600, pp. 83-88, 2006.2

5) Bažant, Z.P. and Zhou, Y. : Why Did the World Trade Center Collapse? -Simple Analysis, J. of Eng. Mech., ASCE, pp. 2-6, 2002.1

6) 李正林, 大井謙一, 伊藤拓海, 嶋脇與助: 進行性崩壊の防止のための 鋼柱の座屈後残存耐力評価, 日本建築学会大会学術講演梗概集, C-1, pp. 775-776, 2004.8

7) 君島祐介, 鈴木弘之: 柱が高温座屈した後の鋼構造架構の進行性崩壊, 日本建築学会大会学術講演梗概集, C-1, pp. 893-894, 2004.8

8) 田川浩之, 山田哲, 和田章：構面外挙動による外周架構の進行性崩壊 現象の解析的再現, 日本建築学会構造系論文集, No.624, pp. 219-226, 2008.2

9) リダンダンシーに優れた鋼構造建築物の研究小委員会：リダンダンシー に優れた鎆構造建築物のための崩壊制御設計ガイドライン，日本鋼構造 協会, 2005.9

10) 山崎真司，見波進，羽田和樹: 中心圧縮を受ける箱形断面鋼柱の完全崩 塤举動, 日本建築学会構造系哃文集, No.631, pp.1657-1664, 2008.9

11) 見波進, 山崎真司, 石井大吾: 銅素材の応力歪関係の数式表現, 構造工 学論文集, Vol.50B, pp.361-365, 2004.3

\section{付録}

付録 1.WTC に対する有効エネルギー吸収率 $\alpha$ の概算

文献 1)の p.79〜 p.90 に記載の建物情報に基づき $\alpha$ の概算值を求める。

1) 基本的な関係式

外周柱とコアー柱が同時に崩壊すると仮定すると，任意の層において， 式 (付1) 〜 (付3) が成立つ.

$$
\alpha=\frac{p_{a}}{p}-1
$$

$$
\begin{aligned}
& p=\frac{P}{P_{y 1}+P_{y 2}}=\frac{1}{\gamma / p_{1}+(1-\gamma) / p_{2}} \\
& p_{a}=\frac{P_{a}}{P_{y 1}+P_{y 2}}=\frac{p_{a 1} \gamma / p_{1}+p_{a 2}(1-\gamma) / p_{2}}{\gamma / p_{1}+(1-\gamma) / p_{2}}
\end{aligned}
$$

ここで, $\alpha$ : 有効エネルギー吸収率, $p$ : 軸力比, $p_{a}$ : 平均耐力比

$P:$ 全軸力, $P_{a}$ : 平均耐力

$P_{y 1}, P_{y 2}:$ 外周柱およびュアー柱の降伏耐力

$p_{1}, p_{2}$ : 外周柱およびュアー柱の軸力比

$p_{a 1}, p_{a 2}$ : 外周柱およびュアー柱の平均耐力比

$\gamma$ :層の全軸力のうち外周柱で負担する軸力の比率

2) $\alpha$ の概算

50, 80, 95 階について $\alpha$ の概算值を求める. 文献 1) より, $p_{1}=0.223$, $p_{2}=0.667, \gamma=0.4$ とする. 外周柱, コアー柱の弱軸に関する断面 2 次 半径 $i_{y}$, 練長比 $\lambda_{y}=L / i_{y}$, 基準化細長比 $\lambda_{c}, p_{a}$ および全体に関する $p$, $p_{a} ， \alpha$ を表付 1 に示す. ここで，柱の圧縮崩壊時に両端と材中央の 3 筒所に 塑性ヒンジが生じると仮定し，座屈長さを階高の $1 / 2(L=3676 / 2 \mathrm{~mm})$ と した. 外周柱の構面外方向およびコアー柱の両方向の梁はピン接合に近いこ と，また，柱の現場継手はメタルタッチによる応力伝達を考虑したディテー ルであることから，この仮定は $p_{a}$ を過大にすなわち $\alpha$ を過大に評価するも

\begin{tabular}{|c|c|c|c|c|c|c|c|c|c|c|c|}
\hline \multirow{3}{*}{ 階 } & \multicolumn{4}{|c|}{ 外周柱 } & \multicolumn{4}{|c|}{ コアー柱 } & \multicolumn{3}{|c|}{ 全体 } \\
\hline & $i_{y}$ & $\lambda_{y}$ & $\lambda_{c}$ & $p_{a 1}$ & $i_{y}$ & $\lambda_{y}$ & $\lambda_{c}$ & $p_{a 2}$ & $p$ & $p_{a}$ & $\alpha$ \\
\hline & $(\mathrm{mm})$ & & $* 2$ & $* 3$ & $(\mathrm{~mm})^{-1}$ & & $* 2$ & *3 & $* 4$ & $* 5$ & $* 6$ \\
\hline$\overline{95}$ & 125 & 14.7 & 0.219 & 0.249 & 102 & 18.0 & 0.200 & 0.274 & 0.371 & 0.257 & -0.307 \\
\hline 80 & 125 & 14.7 & 0.219 & 0.249 & 155 & 11.9 & 0.131 & 0.406 & 0.371 & 0.302 & -0.188 \\
\hline 50 & 122 & 15.1 & 0.224 & 0.243 & 173 & 10.6 & 0.118 & 0.452 & 0.371 & 0.313 & -0.157 \\
\hline \multicolumn{12}{|c|}{ １複数の断面が用いられており， $i_{y}$ は平均值で評㜀した。 } \\
\hline $\begin{array}{l}* 2 \\
* 3 \\
* 4\end{array}$ & $\begin{array}{l}y=4 \\
y=1 \\
21 \text { (付2) } \\
\text { (付3) }\end{array}$ & $\begin{array}{l}18 \mathrm{~N} / \mathrm{m} \\
\text { よる. } \\
\text { によ } \\
\text { によ } \\
\text { によ }\end{array}$ & $\begin{array}{l}\mathrm{m}^{2}(\text { 外 })_{1} \\
\left(\sigma_{B} / \sigma\right. \\
\text {. }\end{array}$ & $\begin{array}{l}\text { 柱), } 2 \\
y=1.2\end{array}$ & $\begin{array}{c}48 \mathrm{~N} / \mathrm{mm}^{2} \\
\text { と仮定) }\end{array}$ & $1^{2}($ (コ) & P-柱) & を用いな & & & \\
\hline
\end{tabular}
のである.

表付1 $p, \quad p_{\alpha}, \alpha$ の概算

(2009年 7 月 7 日原稿受理, 2009年11月 2 日採用決定） 